\title{
Awareness and Utilization on Cooperative Banking Services and Schemes in Rural Area
}

\author{
Niyaz $^{1 *}$ \& Abbokar Siddiq ${ }^{2}$ \\ ${ }^{1}$ Assistant Professor, College of Management and Commerce, \\ Srinivas University, Mangalore, India. \\ OrcidID: 0000-0003-4568-1658; E-mail: niyaz0191@ gmail.com \\ ${ }^{2}$ Associate Professor, Dept. of P. G. Studies in Commerce, \\ University College, Mangalore, India. \\ OrcidID: 0000-0001-7199-7133; E-mail: ugetsiddiq@gmail.com
}

Area/Section: Business Management.

Type of the Paper: Review based Exploratory Research.

Type of Review: Peer Reviewed as per $|\mathrm{C}| \mathrm{O}|\mathrm{P}| \mathrm{E} \mid$ guidance.

Indexed in: OpenAIRE.

DOI: https://doi.org/10.5281/zenodo.5519111

Google Scholar Citation: IJMTS

\section{How to Cite this Paper:}

Niyaz, \& Abbokar Siddiq, (2021). Awareness and Utilization on Cooperative Banking Services and Schemes in Rural Area. International Journal of Management, Technology, and Social Sciences (IJMTS), 6(2), 108-120. DOI: https://doi.org/10.5281/zenodo.5519111

International Journal of Management, Technology, and Social Sciences (IJMTS) A Refereed International Journal of Srinivas University, India.

CrossRef DOI: https://doi.org/10.47992/IJMTS.2581.6012.0157

(C) With Author.

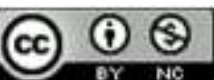

This work is licensed under a Creative Commons Attribution-Non-Commercial 4.0 International License subject to proper citation to the publication source of the work.

Disclaimer: The scholarly papers as reviewed and published by the Srinivas Publications (S.P.), India are the views and opinions of their respective authors and are not the views or opinions of the SP. The SP disclaims of any harm or loss caused due to the published content to any party. 


\title{
Awareness and Utilization on Cooperative Banking Services and Schemes in Rural Area
}

\author{
Niyaz $^{1 *} \&$ Abbokar Siddiq ${ }^{2}$ \\ ${ }^{1}$ Assistant Professor, College of Management and Commerce, \\ Srinivas University, Mangalore, India. \\ OrcidID: 0000-0003-4568-1658; E-mail: niyaz0191@gmail.com \\ ${ }^{2}$ Associate Professor, Dept. of P. G. Studies in Commerce, \\ University College, Mangalore, India. \\ OrcidID: 0000-0001-7199-7133; E-mail: ugetsiddiq@gmail.com
}

\begin{abstract}
Purpose: The purpose of this paper is to study the awareness level and utilization of various cooperative banking services in rural area especially Dakshina Kannada district of Karnataka. In India, most of the states are agriculture dominated, especially in rural area, cooperative banks play a key role in bolstering the common individual and financing his self employment/business and personal needs. The awareness and effective utilization of various rural banking services will improve the financial inclusion statistics of the country. To assess the awareness level, 27 services and schemes offered by the cooperative society are taken and classified into different factors. The awareness levels of rural Muslims are compared with different demographical profile to know the difference.
\end{abstract}

Methodology: Data was collected through a structured questionnaire and distributed among rural Muslims cooperative bank account holders. The study is descriptive in nature and data was collected from 398 rural Muslims of five taluks of Dakshina Kannada district. To draw meaningful inferences, scales for reliability, normality assumption, Mann Whitney $U$ and Kruskal-Wallis test were used to analyze, compare and interpret the data.

Findings: The results indicate that there are no significant differences among the economic status, income and sub-caste regarding awareness of cooperative banking services and schemes. However, there is a significant difference among the age, residence and occupation regarding awareness of cooperative banking services and schemes.

Originality: It may help the service provider to implement services and schemes according to the needs and profile of the rural households in the rural area, in order to have effective utilization of services and to raise the standard of living.

Practical Implication: The findings of the study will help the various stakeholders to overcome the problem of financial inclusion especially in rural areas and help to provide need-based financial service to the rural households in the country.

Paper Type: Analytical Research

Keywords: Cooperative Banking, Financial Inclusion, Rural Muslims, Rural Development

\section{INTRODUCTION :}

In India, nearly $70 \%$ of country's population live in villages [1]. Nearly 3 billion people in the world have complications in accessing formal financial services [2]. About half of India's population is financially excluded [3]. Only 24\% adults in India are financially literate [4]. Slow growth in economic development is due to lack of access to finance for the people of the country [5]. Availability of financial services to the needy people will eradicate poverty and there will be growth in the economy. Credit facilities/good financial assistance will help poor to have better position to improve their socioeconomic conditions [6]. In India, rural households suffer from a great deal of indebtedness and is subject to exploitation in the credit market due to high interest rates and the lack of convenient access to credit. The need for establishing financial institution to rural people, to provide institutional credit to farmers and other rural households was felt to improve the standard of living and to facilitate rural development. There was a need of rural banks for the socio-economic development of rural households

Niyaz, et al, (2021); www.srinivaspublication.com 
in India. There is a saying "Indian farmer is born in debt, lives in debt and dies in debt". In India, in order to alleviate the struggle of the farming community, the Cooperative Credit Societies Act was passed in 1904 which permitted the formation of cooperatives. These cooperatives are not only restricted to agricultural sector but it is also focused on other non-agricultural activities. The cooperatives are the life blood of the Indian economy and the mechanism for any developmental programs. Especially in an agriculture dominated rural sector, cooperative banks play a pivotal role in bolstering the common individual and financing his business and personal needs. Socio-economic improvement of a minority community in India, especially Muslims always have discussions in the country. Majority of rural Muslims are economically backward and financially excluded. Economic backwardness leads to social backwardness and social backwardness leads to further economic backwardness. Most of the rural Muslims fail to avail loan from "Nationalized and Private banks" due to "unable to fulfil the basic formalities, default in previous loan, lack of collateral documents, irregular income and NPA status" etc. Various committees reported the socio-economic condition of Muslim community in India especially Justice Sachar Report, Amitabh Kundu Report, SECC Report, NSSO Report, Justice Ranganath Misra Report, Prof. N.R. Madhava Menon Report, Prof. Abdul Aziz Report and The Annual report by Minority Affairs of both Central, State and District Level. Considering the socio-economic status of particular community both Central and State governments have initiated several schemes to Muslim minority to provide constitutional and legal safeguards as well as certain steps for the overall development of particular community. In rural areas, cooperative banks play a vital role in the development of the economy, whereby most rural households have improved their standard of living. The main goal of establishing cooperative bank in India is to provide credit to the rural people who are not economically strong. At present there are 8, 54,355 Cooperative working in India, 42551 in Karnataka. There are 4,22,731 households in Dakshina Kannada district, of which $65.34 \%$ are rural households [7]. Dakshina Kannada district has the unique distinction of being recognized as the "Cradle of Banks", and is the birthplace for a number of nationalized commercial banks. Among several financial institutions in the district, credit cooperatives have played a vital role in the development of the district. There are 836 cooperative banks in Dakshina Kannada district, of which 02 are Multi-State Level cooperative banks, 03 are State Level, 35 Inter- District, 20 District Level, 36 Inter-Taluk, 55 Taluk Level and 687 Below Taluk Level. About 691 cooperative banks are working profitably, 119 under loss and 26 cooperative banks have no profit or loss. Currently out of the 691,33 of them have stopped functioning (closed). As a result of the increase in the number of branches in rural areas, most rural households, especially Muslims, avail a number of services from cooperative banking. There are 5 Muslim cooperative banks working in Dakshina Kannada district, namely, the Sayyed Madhani Cooperative Society Ltd., Ullala, Millath Credit Co-operative Society Ltd., Bunder, Mangaluru, South Kanara Agriculture Marketing Cooperative Society Ltd., Mangaluru, Amanath Cooperative Bank, Mangaluru, and Standard Mizan Multi-State Cooperative Society, Mangaluru. The district also includes 22 minority cooperative banks focusing on Muslims, Christians, Jain and Buddhists. For the effective utilization of the services and schemes, the banks should evaluate how their products and services reach the customer and to what extent the various services and schemes are benefited to the growth of the society. Most of the rural households, including rural Muslims, prefer to avail loans from cooperative banks due to various reasons. Availability of loans from nationalized banks and other private formal institutions is very difficult for these poor people. There are many examples of the optimistic contribution of cooperative banks to the development of rural households. There is a need for financial support from formal institutions for income-generating activities. In India, most of the households fail to avail loan from nationalized and private banks due to default in previous loan, lack of collateral documents, irregular income, NPA status of a family member, etc. Due to this, most rural households prefer to take loan from moneylenders. Now the trend is changing, and most of the households prefer to avail loan from rural banks, especially, regional rural banks, cooperative banks or societies, district cooperative banks, etc. In India, rural banks were started with the aim of reducing poverty.

Considering the above services of cooperative society and problems faced by Muslim community in availing banking services, this study is a small attempt to understand the importance cooperative banking services in rural area and awareness level and utilization of cooperative banking services and schemes by rural Muslim households in Dakshina Kannada district of Karnataka. 


\section{RELATED WORKS :}

In order to elucidate the research gap and to uphold the objective, the review of literature is conducted. Reviews are collected under two sections; they are (1) Financial Inclusion through Cooperative Banking (2) Cooperative Banking Services in Rural Area.

\subsection{Financial Inclusion through Cooperative Banking}

The growth of the economy depends on the percentage of people having access to various financial services offered by financial institutions. There are a number of factors which affect the access to financial services by the weaker section of the society such as lack of awareness, low income and assets, illiteracy and social exclusion [8]. Rural branch expansion with the opening of branches where there were no banks significantly affected economic growth and it also affected individual savings mobilization, credit disbursement to rural people, increase in total per capita output and sources of employment in rural areas [9]. The development of any community is dependent on how the particular community is involved in the financial aspect. Formal credit to weaker sections of the society will help in improving their socio-economic conditions. Good formal credit will help the improvement of the standard of living of the poor. It will also help to lift poor people above the poverty line [10]. Muslim communities face financial disadvantages due to faith and religious belief, which has excluded them from the financial system [11]. Rural Muslims are more in the unorganized sector like daily wage, selfemployment and in small businesses, which makes them happy in life [12].

\subsection{Cooperative Banking Services in Rural Area}

Cooperative banks concentrate more in providing credit facilities to small farmers and weaker sections of the society. There are many schemes in cooperative banks like free boring facility, dairy scheme, fisheries schemes, schemes for godown, construction of rural houses, etc. Most of beneficiaries of the above schemes are only the small and marginal farmers [13]. Cooperative banks showed a significant development in the rural area. Rural cooperatives accelerated the process of rural development in remote India and also played very important role in improving the standard of living [14]. There was substantial progress in the resources of cooperative banks. The operational efficiency showed better. It was suggested there was need for wide resources mobilization, better supervision, and rational fund allocation [15] and there was need for professionalism in the management of cooperative banks. Some of the rural area cooperatives also failed to accumulate funds due to poor resource base, high transaction costs, lack of professional management, and business diversification [16]. For the development of the bank, there is a need for proper strategy to empower cooperative banks and to remove the overlapping of control between both central and state government. Cooperative banks needed a strong resource base, professionalization of management, proper human resource development, and freedom to deploy funds only for business consideration [17]. Cooperative banks found it difficult to identify the beneficiaries because most cooperatives do not give importance to field staff in rural branches and banks should redefine the role and focus more on identification of beneficiaries and effective supervision for end-use of credit [18]. Cooperative banks also face so many challenges because customers are dissatisfied with the administration and utilization of subsidy. There were many complaints that the amount of subsidy was not reaching all the beneficiaries and a large portion of the amount was misappropriated by government and bank officials, including middlemen [19].

\section{OBJECTIVES :}

The study is intended to know the awareness and utilization of various Cooperative banking services and schemes by the rural Muslim communities in the study area. The study also analyses whether the demographical variables will have difference on awareness level on various cooperative banking services and schemes.

\section{HYPOTHESIS :}

Hypothesis is developed to examine whether demographic profile of rural customer have significant difference in the awareness level. It is formulated as follows;

$\mathbf{H}_{\mathbf{1}}$ : The demographical profile of rural Muslim customer influences the awareness on various banking services and schemes of cooperative banking. 


\section{METHODOLOGY :}

This study is focused on determining the awareness level and usage of various services and schemes provided by the cooperatives in coastal Karnataka. Descriptive research design has been followed in this study and it aims to analyze the respondents' awareness level and usage of various services and schemes.

Questionnaire consists of two parts; first part is related to demographical and second part consists of awareness and utilization of various cooperative banking services and schemes. Here, awareness and utilization of various cooperative banking services and schemes was measured by 27 statements. Based on factor analysis, it has been categorized in to four factors namely 1) Type of Schemes (TS) was measured by seven statements, and (2) Type of Loans (TL) was measured by eight statements; (3) Basic and E-Banking Services (B\& E-B) was measured by seven statements and the (4) Agriculture Oriented Service (AOS) was measured by five statements.

After constructing questionnaire, a pilot study was conducted to know the feasibility and understandability of the questionnaire. In the pilot study, it was found feasible and understandable to the rural Muslim community. Later, data was collected from 398 rural Muslim communities in Dakshina kannada district. The study was carried out by taking five taluks of Dakshina kannada district such as Mangaluru, Bantwal, Puttur, Belthangady and Sullia. Questionnaire was distributed using a Proportional stratified sampling method. Sampling frame was designed with the help of enrollment details provided by each university's website. Later, based on the number of students from university, sample has been selected using Taro Yamane formula. Second part of the questionnaire measures students' awareness and utilization of various cooperative banking services and schemes by asking statements in five-point Likert scale, where ,1 was Fully Unaware (FU), 2 was Unaware (D), 3 was Neutral (N), 4 was Aware (A) and 5 was Fully Aware (FA). After collecting the data, the responses were recorded in SPSS and reliability test was conducted for components of Awareness level on Cooperative Banking Services and schemes. The table No.1 exhibits the Cronbach's value for Awareness level on Cooperative Banking Services is 0.756. as per Hair et al. 2010, the Cronbach Alpha fulfils the condition, the results show the value above 0.7 .

Table 1: Reliability and Validity Results

\begin{tabular}{|c|c|c|}
\hline Variables & Cronbach's Alpha & Number of Items \\
\hline $\begin{array}{c}\text { Awareness on Cooperative } \\
\text { Banking Services and Schemes }\end{array}$ & 0.756 & 27 \\
\hline \multicolumn{2}{|c|}{} & Source: Data Analysis \\
\hline
\end{tabular}

Testing the Assumption of Normality: The present study is based on the skewness and Kurtosis value of normality of the data has been decided. The present data which is measured in metric does not full fill the condition of normality, So, based on distribution of the group, categorical variable and metric, non-parametric test have been used for the study. Mann Whitney U and Kruskal-Wallis test are used to know the significant difference among the demographical variable with respect to awareness level of various cooperative banking services and schemes.

\section{RESULTS AND DISCUSSION :}

Data collected was tabulated and analysis was carried out by using Simple percentage analysis, Descriptive analysis using mean and standard deviation and inferential analysis such as factor analysis, Mann Whitney U and Kruskal-Wallis test. Data was analyzed as follows;

\subsection{Sample Profile}

Sample profiles were collected to know the background of the students such as age, educational Qualification, residence, sub-caste, economic status, occupation and Income. This will help us to understand the diversity of students in research area. The details are given below,

Table 2: Sample Profile

\begin{tabular}{|l|l|l|}
\hline \multicolumn{1}{|c|}{ Variable } & No. of Respondents & Percentage \% \\
\hline Age (in Years) & \multicolumn{2}{l|}{} \\
\hline
\end{tabular}




\begin{tabular}{|c|c|c|}
\hline$\leq 25$ & 32 & 8.0 \\
\hline $26-35$ & 184 & 46.2 \\
\hline $36-45$ & 143 & 35.9 \\
\hline$>45$ & 39 & 9.8 \\
\hline \multicolumn{3}{|l|}{ Educational Qualification } \\
\hline Illiterate & 30 & 7.5 \\
\hline Primary Level & 108 & 27.1 \\
\hline High School Level & 139 & 34.9 \\
\hline SSLC & 64 & 16.1 \\
\hline PUC & 26 & 6.5 \\
\hline ITI/Diploma & 8 & 2.0 \\
\hline Undergraduate & 16 & 4.0 \\
\hline Postgraduate $\&$ above & 7 & 1.8 \\
\hline \multicolumn{3}{|l|}{ Residence Taluks } \\
\hline Mangaluru & 71 & 17.8 \\
\hline Bantwal & 160 & 40.2 \\
\hline Puttur & 67 & 16.8 \\
\hline Belthangady & 63 & 15.8 \\
\hline Sullia & 37 & 9.3 \\
\hline \multicolumn{3}{|l|}{ Sub-Caste } \\
\hline Shafi & 262 & 65.8 \\
\hline Hanafi & 136 & 34.2 \\
\hline \multicolumn{3}{|l|}{ Economic Status } \\
\hline BPL & 327 & 82.2 \\
\hline APL & 71 & 17.8 \\
\hline \multicolumn{3}{|l|}{ Occupation } \\
\hline Agricultural Labourer & 8 & 2.0 \\
\hline Beedi Contractor & 10 & 2.5 \\
\hline Auto Garage & 22 & 5.5 \\
\hline Coolie/Daily Wage & 32 & 8.0 \\
\hline Driver & 94 & 23.6 \\
\hline Conductor & 8 & 2.0 \\
\hline Fish Vendor & 62 & 15.5 \\
\hline Petty Shop/Small Grocery Shop & 32 & 8.0 \\
\hline Building Contractor & 8 & 2.0 \\
\hline Scrap Business & 24 & 6.0 \\
\hline Self-Employment & 78 & 19.6 \\
\hline Private Employees & 12 & 3.0 \\
\hline Real Estate/Land Links & 4 & 1.0 \\
\hline Timber Contractor & 4 & 1.0 \\
\hline \multicolumn{3}{|l|}{ Income } \\
\hline Less than 10,000 & 16 & 4.0 \\
\hline 10,000 to 20,000 & 104 & 26.1 \\
\hline 20,000 to 30,000 & 167 & 42.0 \\
\hline 30,000 to 40,000 & 64 & 16.1 \\
\hline 40,000 to 50,000 & 23 & 5.8 \\
\hline Above 50,000 & 24 & 6.0 \\
\hline
\end{tabular}

Source: Survey Data

The table 2 explains the demographic of the respondents which indicates that $46.2 \%$ of the respondents belong to the age group of 26 to 35 and are female. It exhibits that $69.5 \%$ of the rural Muslim community in the study area possess education level of high school and below. While considering residence majority (40.2\%) of the respondents are from Bantwal taluk and 17.8 per cent are from Mangaluru. The table exhibits that 65.8 per cent of the rural Muslim customers are from the five taluks of Dakshina 
Kannada and they belong to the Shafi sub-caste and the remaining 34.2 per cent belong to the Hanafi sub-caste. Majority $(82.2 \%)$ of the respondents are below poverty line and remaining $17.8 \%$ are above the poverty line. 23.6 per cent respondents are working as drivers, $19.6 \%$ of the respondents are SelfEmployed and $15.5 \%$ respondents are working as Fish vender. It also revealed that large majority (42.0\%) of the respondents' income is between 20,000 to 30,000 followed by $26.1 \%$ between 10,000 to 20,000

\subsection{Descriptive Statistics and Usage Pattern of Cooperative Banking Services and Schemes}

The respondents were asked to indicate their awareness on various cooperative banking services and schemes. The awareness level was measured on the five-point Likert scale with $1=$ Fully Unaware and $5=$ Fully Aware using twenty-seven items and Usage pattern collected using 'Yes' or 'No' Questions. The results of the sample are shown in below Table 3 .

Table 3: Awareness and Usage Pattern of Cooperative Banking Services and Schemes

\begin{tabular}{|c|c|c|c|c|}
\hline \multirow[b]{2}{*}{ Service and Schemes } & \multirow[b]{2}{*}{ Mean } & \multirow[b]{2}{*}{ S.D. } & \multicolumn{2}{|c|}{ Utilized } \\
\hline & & & Frequency & $\begin{array}{c}\text { Percentage } \\
\%\end{array}$ \\
\hline Home loan/Pledge/ Mortgage & 4.3241 & .55704 & 119 & 29.9 \\
\hline Education loan & 4.3191 & .56443 & 6 & 1.5 \\
\hline Small business loan & 4.2513 & .64834 & 80 & 20.1 \\
\hline Vehicle loans & 4.2588 & .65118 & 232 & 58.3 \\
\hline Petty loan & 4.2739 & .55241 & 13 & 3.3 \\
\hline Other purpose loan & 4.2462 & .65413 & 160 & 40.2 \\
\hline Personal loan & 4.2663 & .55383 & 24 & 6.0 \\
\hline Gold loan & 4.3090 & .56557 & 223 & 56.0 \\
\hline Interest subsidy for crop loans schemes & 2.7563 & 1.39571 & 4 & 1.0 \\
\hline $\begin{array}{l}\text { SHG's Loan -BPL Card holder/Interest } \\
\text { Subvention for loans to SHGs }\end{array}$ & 1.8970 & 1.41312 & 0 & 0.0 \\
\hline Kayaka scheme-group activity & 1.8920 & 1.38938 & 0 & 0.0 \\
\hline Yeshasvini cooperative health scheme & 1.7487 & 1.35869 & 16 & 4.0 \\
\hline $\begin{array}{l}\text { PMFBY (Pradhan Mantri Fasal Bima } \\
\text { Yojana) }\end{array}$ & 1.7487 & 1.35869 & 6 & 1.5 \\
\hline Navodaya self-help group scheme & 1.9095 & 1.41665 & 55 & 13.8 \\
\hline Loan for agricultural land purchase & 2.7789 & 1.40935 & 69 & 17.3 \\
\hline Medium-term loan for asset creation & 2.7462 & 1.39211 & 6 & 1.5 \\
\hline $\begin{array}{l}\text { Emergency loan through storage of } \\
\text { agricultural-product }\end{array}$ & 3.3819 & 1.52060 & 4 & 1.0 \\
\hline $\begin{array}{l}\text { Kisan Credit Card (KCC)/Short-term loan } \\
\text { with zero per cent interest/Crop loan }\end{array}$ & 2.7714 & 1.41617 & 0 & 0.0 \\
\hline Badawara bandu scheme & 1.8769 & 1.37719 & 6 & 1.5 \\
\hline Type of deposits and withdrawals & 3.1834 & 1.20829 & 398 & 100.0 \\
\hline Type of account service & 3.1784 & 1.23584 & 398 & 100.0 \\
\hline Agricultural inputs schemes & 1.8869 & 1.40699 & 9 & 2.3 \\
\hline SMS Alert & 2.6658 & 1.27023 & 56 & 14.1 \\
\hline Storage facility & 3.1658 & 1.19514 & 6 & 1.5 \\
\hline Locker Facility & 3.1683 & 1.19373 & 32 & 8.0 \\
\hline
\end{tabular}




\begin{tabular}{|l|l|l|l|c|}
\hline Rupay Card/ATM/Debit Card & 3.2111 & 1.22554 & 63 & 15.8 \\
\hline E-payment /EFTs/NEFT/RTGS & 2.6583 & 1.26524 & 32 & 8.0 \\
\hline$N=398$ & $M R \boldsymbol{R}=5.07$ & Source $:$ Survey
\end{tabular}

\section{Data}

Considering the above table, the awareness level on various cooperative banking services and schemes shows the mean and S.D. ranges from 1.74 and $4.32 \& 0.55$ to 1.52 with lowest rating 1 and maximum rating of 5. The respondents rated above average point 3, except for e-payment, SMS alert, agricultural input schemes, Badawara bandu scheme, crop loan, interest subsidy for crop loans schemes, SHG's Loan to BPL cardholder, kayaka scheme, yeshasvini cooperative health Scheme, PMFBY, navodaya self-help group scheme, loan for agricultural land purchase, and medium-term loan for asset creation. It shows that customers are aware of most of the services and schemes offered by cooperative banks. Still, there is a need for creating more awareness on some new schemes like Badawara bandu scheme, SHG's loan-BPL cardholder/interest subvention for loans to SHGs, and kayaka scheme-group activity. Considering the usage pattern of rural muslims in Dakshina kannada district, 29.9 per cent of the respondents have used home loan/pledge loan/mortgage loan services, a minor 1.5 percent of the respondents have used education loan services, 20.1 per cent of the respondents have used small business loan services, 58.3 per cent have used vehicle loans services, 3.3 per cent have used petty loans services, 40.2 per cent have used other purpose loan (OP Loan), 6 per cent have used personal loan services, 56 per cent have used gold loan services, only 1 per cent used Interest subsidy for crop loans schemes, none of the respondents has availed the benefit of SHG's Loan, Kayaka scheme, and Kisan Credit Card, 4 per cent have availed the benefit of the Yeshasvini Co-operative Health Scheme, 1.5 per cent have availed the benefit of the Pradhan Mantri Fasal Bima Yojana, and 13.8 per cent have availed the benefit of the Navodaya self-help group scheme.

Further, it is also seen that 17.3 per cent of the respondents have taken a loan for the purchase of land, 1.5 per cent for asset creation, 1 per cent have taken emergency loan through storage of agricultural product, and 1.5 per cent have availed the benefit of the badawara bandu scheme. All the respondents have used the deposit and withdrawal services and account services offered by the banks. It is also revealed that only 2.3 per cent of the respondents have availed the benefit of the agricultural input schemes, while 97.7 per cent have not availed its benefit. About 14.1 per cent of the respondents have used SMS alert services, 1.5 per cent have used storage services, 8 per cent have used the locker facility, 15.8 per cent have used Rupay Card/ATM/Debit Card services, and 8 per cent have used the e-payment/ EFTs/NEFT/RTGS services. The results show that deposits and withdrawals, type of account service, gold loan, vehicle loans, other purpose loan, and home loan/pledge/mortgage play a very important role as majority of the respondents have used these services and schemes from cooperative banking in Dakshina Kannada district.

\subsection{Factor Analysis Awareness on various Cooperative Banking Services and Schemes}

Factor analysis was done using two statistical tests, namely, Kaiser-Meyer-Olkin (KMO) test and Bartlett's test. In the present study, factorization of Awareness on various Cooperative Banking Services and Schemes was done. KMO and Bartlett's test used to measure sample adequacy.

According to Field (2009), KMO values between 0.7 and 0.8 are good and between 0.8 and 0.9 are great, and values above 0.9 are excellent, all the values show above 0.7 , the factor analysis is appropriate.

Table 4: Factor Loadings Factor of Awareness on various Cooperative Banking Services and Schemes

\begin{tabular}{|l|c|c|c|c|c|}
\hline \multicolumn{1}{|c|}{ Factor of Awareness } & \multicolumn{3}{c|}{ Component } & \multirow{2}{*}{ Factor's Name } \\
\cline { 2 - 5 } & $\mathbf{1}$ & $\mathbf{2}$ & $\mathbf{3}$ & $\mathbf{4}$ & \\
\hline $\begin{array}{l}\text { SHG's loan-BPL card holder/ } \\
\text { Interest subvention for loans to } \\
\text { SHGs }\end{array}$ & .988 & & & & \multirow{2}{*}{ Type of Schemes } \\
\hline Agricultural input schemes & .987 & & & & \\
\hline Navodaya self-help group scheme & .986 & & & & \\
\hline Kayaka scheme group activity & .983 & & & & \\
\hline
\end{tabular}




\begin{tabular}{|c|c|c|c|c|c|}
\hline Badawara bandu scheme & .980 & & & & \\
\hline $\begin{array}{l}\text { PMFBY (Pradhan Mantri Fasal } \\
\text { Bima Yojana) }\end{array}$ & .927 & & & & \\
\hline $\begin{array}{l}\text { Yeshasvini cooperative health } \\
\text { scheme }\end{array}$ & .926 & & & & \\
\hline Small business loan & & .858 & & & \multirow{8}{*}{ Type of Loans } \\
\hline Other purpose loan & & .855 & & & \\
\hline Vehicle loan & & .848 & & & \\
\hline Education loan & & .768 & & & \\
\hline $\begin{array}{l}\text { Home loan/pledge /mortgage /land } \\
\text { purchase loan }\end{array}$ & & .767 & & & \\
\hline Personal loan & & .766 & & & \\
\hline Petty loan & & .760 & & & \\
\hline Gold loan & & .759 & & & \\
\hline Locker facility & & & .950 & & \multirow{7}{*}{$\begin{array}{c}\text { Basic/ } \\
\text { E-Banking } \\
\text { Services }\end{array}$} \\
\hline Storage facility & & & .950 & & \\
\hline Type of deposits and withdrawals & & & .945 & & \\
\hline Rupay card/ATM/Debit card & & & .940 & & \\
\hline e-payment/EFTs/NEFT/RTGS & & & .720 & & \\
\hline SMS alert & & & .719 & & \\
\hline Type of account service & & & .651 & & \\
\hline $\begin{array}{l}\text { Kisan Credit Card (KCC)/short- } \\
\text { term loan with zero per cent } \\
\text { interest/crop loan }\end{array}$ & & & & .913 & \multirow{5}{*}{$\begin{array}{c}\text { Agriculture } \\
\text { Oriented Services }\end{array}$} \\
\hline Loan for agricultural land purchase & & & & .912 & \\
\hline $\begin{array}{l}\text { Interest subsidy for crop loan } \\
\text { schemes }\end{array}$ & & & & .902 & \\
\hline $\begin{array}{l}\text { Medium-term loan for asset } \\
\text { creation }\end{array}$ & & & & .901 & \\
\hline $\begin{array}{l}\text { Emergency loan through storage of } \\
\text { agricultural product }\end{array}$ & & & & .811 & \\
\hline
\end{tabular}

Source: Survey Data

\section{Analysed}

\section{Type of Schemes}

It can be inferred from the above table that SHG's Loan-BPL card holder/Interest Subvention for loans to SHGs, Agricultural input schemes, Navodaya self-help group scheme, Kayaka scheme-group activity, Badawara bandu scheme, PMFBY (Pradhan Mantri Fasal Bima Yojana), and Yeshasvini cooperative health scheme are the most important items from the cooperatives.

Type of Loans

Type of loan consists of eight variables concerned with the type of loan service. It includes small business loan, other purpose loan, vehicle loan, education loan, home loan/pledge/ mortgage/land purchase loan, personal loan, petty loan, and gold loan.

\section{Basic and E-Banking Services}

This factor consists of seven variables, namely, locker facility, storage facility, type of deposits and withdrawals, Rupay Card/ATM/Debit card, e-payment/ EFTs/ NEFT/ RTGS, SMS alert, and type of account service.

\section{Agriculture Oriented Services}

This factor focused on agricultural oriented services provided by cooperative banks. It includes five variables, namely, Kisan Credit Card (KCC)/short-term loan with zero per cent interest/crop loan, loan for agricultural land purchase, interest subsidy for crop loans schemes, medium-term loan for asset creation, and emergency loan through storage of agricultural-product. 


\subsection{Hypotheses Testing}

The hypothesis is developed to support the objective of the study. The hypotheses are tested and analyzed as follows,

$\mathrm{H}_{1}$ : The awareness level of cooperative banking services and schemes among Muslims in rural areas is dependent on the demographical profile.

In order to test the above hypothesis, sub hypothesis are developed, they are;

$H_{l} a$ : There is a significant difference in the awareness level of cooperative banking services and schemes among age group.

$H_{l} b$ : There is a significant difference in the awareness level of cooperative banking services and schemes among Educational Qualification

$H_{1}$ : There is a significant difference in the awareness level of cooperative banking services and schemes among residence

$H_{l} d$ : There is a significant difference in the awareness level of cooperative banking services and schemes among shafi and hanafi muslims

$H_{l}$ : There is a significant difference in the awareness level of cooperative banking services and schemes among BPL and APL ration card holder

HIf: There is a significant difference in the awareness level of cooperative banking services and schemes among Occupation

HIg: There is a significant difference in the awareness level of cooperative banking services and schemes among Income

The results of hypothesis testing are discussed below,

In order to know whether there is a significant difference in the awareness level of rural Muslim community on cooperative banking services and schemes among different demographical variable, Mann Whitney U and Kruskal Wallis H was used and result is discussed as follows,

Variable: Awareness on Cooperative Banking Services and Schemes

Table 5: Mean difference among different demographical with respect awareness on various cooperative banking services and schemes

\begin{tabular}{|c|c|c|c|}
\hline Demographical Variable & Mean Rank & $Z$ value & P value \\
\hline \multicolumn{4}{|l|}{ Age } \\
\hline Up to 25 & 151.89 & \multirow{4}{*}{15.443} & \multirow{4}{*}{$\mathbf{P}<0.01 * *$} \\
\hline 26 to 35 & 189.87 & & \\
\hline 36 to 45 & 224.43 & & \\
\hline Above 45 & 192.59 & & \\
\hline \multicolumn{4}{|l|}{ Educational Qualification } \\
\hline Illiterate & 206.37 & \multirow{8}{*}{5.792} & \multirow{8}{*}{$\mathrm{P}>0.05$} \\
\hline Primary & 190.55 & & \\
\hline High School & 196.90 & & \\
\hline SSLC & 207.41 & & \\
\hline PUC & 241.00 & & \\
\hline ITI/DIPLOMA & 191.56 & & \\
\hline UG & 184.78 & & \\
\hline PG \& above & 175.93 & & \\
\hline \multicolumn{4}{|l|}{ Residence } \\
\hline Mangaluru & 174.66 & \multirow{5}{*}{21.562} & \multirow{5}{*}{$\mathbf{P}<0.01 * *$} \\
\hline Bantwal & 181.31 & & \\
\hline Puttur & 225.04 & & \\
\hline Belthangady & 217.33 & & \\
\hline Sullia & 249.19 & & \\
\hline \multicolumn{4}{|l|}{ Sub-caste } \\
\hline Shafi & 199.76 & 0.066 & $\mathrm{P}>0.05$ \\
\hline
\end{tabular}




\begin{tabular}{|c|c|c|c|}
\hline Hanafi & 199.00 & & \\
\hline \multicolumn{4}{|l|}{ Economic Status } \\
\hline BPL & 198.01 & \multirow{2}{*}{0.592} & \multirow{2}{*}{$\mathrm{P}>0.05$} \\
\hline APL & 206.38 & & \\
\hline \multicolumn{4}{|l|}{ Occupation } \\
\hline Agricultural labourer & 152.69 & \multirow{13}{*}{20.257} & \multirow{13}{*}{$\mathrm{P}<0.05 *$} \\
\hline Auto Garage & 202.70 & & \\
\hline Coolie/Daily Wage & 199.77 & & \\
\hline Drivers & 171.44 & & \\
\hline Conductors & 157.63 & & \\
\hline Fish-Vendor & 188.97 & & \\
\hline Petty Shop/Small Grocery Shop & 172.53 & & \\
\hline Building Contractor & 281.13 & & \\
\hline Scrap Business & 199.98 & & \\
\hline Self-employment & 224.44 & & \\
\hline Private Employees & 179.29 & & \\
\hline Real Estate/Land Links & 211.64 & & \\
\hline Timber Contractor & 202.35 & & \\
\hline \multicolumn{4}{|l|}{ Income } \\
\hline Less than 10,000 & 194.31 & \multirow{6}{*}{33.429} & \multirow{6}{*}{$\mathrm{P}>0.05$} \\
\hline 10,001 to 20,000 & 181.55 & & \\
\hline 20,001 to 30,000 & 206.98 & & \\
\hline 30,001 to 40,000 & 196.57 & & \\
\hline 40,001 to 50,000 & 197.57 & & \\
\hline Above 50,000 & 238.40 & & \\
\hline
\end{tabular}

**Significant at $1 \%$ level of significant significant

*Significant at $5 \%$ level of

Table 5 exhibits the Mann Whitney $\mathrm{U}$ and Kruskal Wallis $\mathrm{H}$ test result for mean difference in the awareness level among various demographical variable. It showed that there is a high significant mean difference among different age group and residence or locality with respect to the awareness level of rural Muslim community on cooperative banking services and schemes. H1 is accepted at $5 \%$ level. While considering the different occupations of rural Muslim community, there is a significant difference in the mean value in respect of awareness level, as the p value is less than 0.05 . $\mathrm{H} 1$ is accepted at 5\% level.

Considering the Educational Qualification, Sub-Caste, Economic Status and Income, there is no significant mean difference in the awareness level of rural Muslims, as the $\mathrm{p}$ value is more than 0.05. $\mathrm{HO}$ is accepted.

\section{CONCLUSION :}

The cooperative bank is the best platform for the development of the rural people. The major literate of the study justifies that the cooperative banks contribute to the empowerment of rural people by providing various financial services and making them financially strong, as well as helping them to save 
money and invest it for further development. This study shows that, there is some extent of utilization of various cooperative banking services and schemes. The banks have to focus more in creating awareness, especially for new schemes and services and also give importance to better utilization of services and schemes.

\section{PRACTICAL IMPLICATION OF THE STUDY :}

The findings of the study have several implications for the rural Muslim community, cooperative banks, academicians, researchers and policymakers. This study gives a clear picture that there is a need for empowerment at the grassroot level, especially for rural communities by creating more awareness about the importance of education, social security, savings and spending habit or importance of financial inclusion and problems of borrowing loan from non-financial institutions sources. The study has also identified the lack of awareness among rural Muslim community on various banking schemes provided by cooperative banks. Here, bank can have separate team for creating awareness among rural masses about the various development schemes through cooperative banks. This study may help the Government, bankers, community developers, and NGO to come out with a strategy for the development of the rural Muslim community by providing easy availability of financial assistance through various banking systems, which thereby will help to improve their standard of living. The better utilization of financial services and schemes by the needy people in the country will help in the improvement in the socio-economic status, this will have a great contribution to the economy.

\section{DIRECTION FOR FUTURE STUDY :}

The present study attempts to know the awareness and utilization level of various cooperative banking services and schemes especially among Muslim community in Dakshina Kannada district of Karnataka. Study can be undertaken to know the impact of Central and State government schemes on the socioeconomic development of rural Muslims in India. The difference in the approaches of cooperative banks and nationalized banks towards the financial inclusion of rural Muslim community in India could be another focus area for further research. Research in the area of identification of differences in the spending and saving behaviours of Muslim community with other socio-religious categories can be undertaken. Further research could be undertaken to know the role of cooperative banks in the financial inclusion of schedule caste and schedule tribe communities in the rural area.

\section{REFERENCES :}

[1] Chandramauli, C. (2013). Census of India-2011, Office of the Registrar General \& Census Commissioner, India Ministry of Home Affairs, Government of India. Downloaded on 12/01/2017.

[2] Kumar, C., \& Mishra, S. (2011). Banking Outreach and Household level Access: Analyzing Financial Inclusion in India, 13th Annual Conference on Money and Finance in the Indian Economy, Mumbai, India. Downloaded on 14/01/2017.

[3] World Bank. (2007). Providing Financial Services in Rural Areas a Fresh Look at Financial Cooperatives, Agriculture and Rural Development Department World Bank. Downloaded on $08 / 02 / 2017$.

[4] Klapper, L. \& Lusardi, A. (2014). Financial literacy and financial resilience: Evidence from around the world. Financial Management-WILEY, 49, 589-614.DOI:10.1111/fima.12283

[5] Mainuddin, M. (2011). Socio-Economic Conditions and Political Representation of Indian Muslims: A Study of West Bengal. Corpus ID: 212550476

[6] Jasbir, S.K., \& Deb, P.C. (1985). Socio-Economic Impact of IRDP in Punjab. Kurukshetra, 33(11), 29-32.

[7] Socio-economic and Caste Census. (2011). Department of Rural Development, Ministry of Rural Development, Government of India. Downloaded on 12/01/2017.

[8] Ravichandran, D., \& Alkhathlan, D. (2009). Financial Inclusion-A Path towards India's Future Economic Growth. Available at SSRN 1353125.

[9] Burgess., \& Pande. (2005). Do Rural Banks Matter? Evidence from the Indian Social Banking Experiment. American Economic Review, 95(3), 780-795. 
[10] Subramanya, S. (1986). "Trends and Progress of banking in India", Deep and Deep Publications, New Delhi, 1986, pp.164.

[11] Pearson, G. (2008). 'Reconceiving Regulation: Financial Literacy'. Macquarie Law Journal, 8(8), $45-58$

[12] Justice Sachar. (2006). 'Social, Economic and Educational Status of the Muslim Community of India,' Ministry of Human Resource Development, Government of India. Downloaded on 24/03/2017.

[13] Gupta, S.K. (1996). A Critical Study of the Role of Land Development Banks in the Agricultural Development of U.P. with special reference to Etawah District, Doctoral Thesis, Shri Sadhu JI Maharaj, Kanpur University, Kanpur.

[14] Amit, K., Chakrabarty., \& Krishnamay, G. (2009). "Appraisal of a rural cooperative with the thrust on rural development: An empirical study". International Journal of Social Economics, $36(1 / 2), 199-211$.

[15] Jangid, S. N. (1976). Cooperative Banking in Punjab, Doctoral Thesis, University Business School, Panjab University, Chandigarh

[16] Joshi (1997). Basic Tenets of Customer Service. IBH Bulletin, March Issue, 83 - 85.

[17] Kamesam, V. (2001). Credit through Cooperative: Some Thoughts. Accessed from https://www.rbi.org.in/scripts/BS_SpeechesView.aspx?Id=83

[18] National Bank for Agriculture and Rural Development. (1998). Issues in Rural Development, NABARD, Mumbai.

[19] Lakshmi, N.M., \& Jaya, R.G. (1999). 'Rural Poverty and Anti-Poverty Programme'. Discovery Publishing house, 31. 